University of Nebraska - Lincoln

DigitalCommons@University of Nebraska - Lincoln

USDA National Wildlife Research Center - Staff Publications
U.S. Department of Agriculture: Animal and Plant Health Inspection Service

August 2003

\title{
Monitoring predators to optimize their management for marine turtle nest protection
}

\author{
Richard M. Engeman \\ USDA-APHIS-Wildlife Services, s_r100@yahoo.com \\ R. Erik Martin \\ Ecological Associates, Inc. \\ Bernice Constantin \\ USDA-APHIS-Wildlife Services \\ Ryan Noel \\ Hobe Sound NWR \\ John Woolard \\ USDA-APHIS-Wildlife Services
}

Follow this and additional works at: https://digitalcommons.unl.edu/icwdm_usdanwrc

Part of the Environmental Sciences Commons

Engeman, Richard M.; Martin, R. Erik; Constantin, Bernice; Noel, Ryan; and Woolard, John, "Monitoring predators to optimize their management for marine turtle nest protection" (2003). USDA National Wildlife Research Center - Staff Publications. 215.

https://digitalcommons.unl.edu/icwdm_usdanwrc/215

This Article is brought to you for free and open access by the U.S. Department of Agriculture: Animal and Plant Health Inspection Service at DigitalCommons@University of Nebraska - Lincoln. It has been accepted for inclusion in USDA National Wildlife Research Center - Staff Publications by an authorized administrator of DigitalCommons@University of Nebraska - Lincoln. 


\title{
Monitoring predators to optimize their management for marine turtle nest protection
}

\author{
Richard M. Engeman ${ }^{a}$ *, R. Erik Martin ${ }^{\mathrm{b}}$, Bernice Constantin ${ }^{\mathrm{c}}$, \\ Ryan Noel ${ }^{\mathrm{d}, 1}$, John Woolard ${ }^{\mathrm{c}}$ \\ "Vatonal Wildlife Research Center, 4101 LaPorte Avenue. Fort Collins. CO 80521-2154. LSA \\ ${ }^{\mathrm{b}}$ Ecological Associate's, Wh.. PO Box 405 . Jensen Beach. FI. 349,58. I:SA \\ 'USDA APHIS WS, 2820 East Lniversity A vente. Gainesille. FL 32641. USA \\ "Hohe Somd NHR, 3640 S.E. Federal Hwy. Hobe Sotnd, FL 33455, ESA
}

Received 20 January 2002: received in revised form 5 July 2002; accepted 16 September 2002

\begin{abstract}
The fundamental conservation focus for Hobe Sound Vational Wildlife Refuge (HSNWR). Florida is to provide protected nesting habitat for three threatened or endangered marine turtle species. Turtle nesting and hatching spans from early spring to fall each year. Left unchecked, nest predation by raccoons and armadillos would destroy most turtle nests. Predators are removed to protect nests, primarily with a one person-month contract using control specialists. We maximized the efficiency of predator removal by using a passive tracking index to: (1) optimize the timing and strategy for predator removal, (2) minimize labor by identifying areas where predator removal would have maximal effect, (3) examine beach invasion patterns of predators, (4) assess efficacy of removal efforts. (5) provide anticipatory information for future turtle nesting seasons, and (6) serve as a detection method for invasion by additional species known to depredate turtle nests. An overall nest predation rate of $28 \%$ resulted, whereas the rate for the previous year was $42 \%$ when the same level of contracted predator removal was applied, but without monitoring predators. One year before that, predator removal was done without contracts with specialists and predation was $48 \%$. Up to $95 \%$ of the nests were destroyed in the years prior to predator removal. Using 2000 data on numbers of nests. clutch sizes, and emergence rates, we estimated the number of hatchlings that would have been lost assuming that the predation rates observed from four predator removal scenarios at HSNWR would have occurred in 2000 . Historical predation of $95 \%$ would have resulted in 120,597 hatchlings lost in 2000. Predator removal as part of regular refuge operations would have reduced this number to 62,481. Addition of a contract with control specialists would have further reduced the number lost to 53.778. Addition of temporal and spatial monitoring for predator removal reduced losses to $36,6,37$.
\end{abstract}

Published by Elsevier Science Lid.

Ke 1words: Armadillo: Florida; Leatherback turtle: Loggerhead turtle: Green turtle: Population index: Raccoon

\section{Introduction}

Urbanization and development of coastal Florida have reduced the beach areas where marine turtles successfully nest. In contrast. raccoons Procyon lotor have prospered in the face of urbanization, and flourish in close association with humans where their populations

\footnotetext{
* Corresponding author. Tel.: + 1-970-266-6091: fax: + 1-970-2666089 .

E-mail adtress: richard m.engemana usda.gov (R.M. Engeman).

1 Present itddress: Santee NWR. 2125 Fort Watson Road. Summerton. SC 29148. USA
}

often receive artificial support through refuse or direct feeding (Riley et al., 1998: Dickman, 1987; Dickman and Doncaster, 1987; Smith and Engeman, in press). Raccoons cause substantial destruction of marine turtle nests in Florida and throughout the southeastern United States (Stancyk, 1982). examplifying an abundant native vertebrate that impacts the conservation of endangered species (e.g. Garrott et al., 1993). Armadillos Dasypus novemcinctus are an exotic species in Florida (Schmitz and Brown. 1994) that were recently identified as another primary predator on marine turtle nests (Drennen et al., 1989). At some beaches their predation has risen to levels similar to that from raccoons 
(Bain et al.. 1997). Besides direct predation, raccoons and armadillos also expose the nests to the elements and to predation by crabs, birds, and other mammal species.

Predation is a critical threat to many endangered or even locally rare species (Hecht and Nickerson, 1999). and predation losses can have an increased deleterious impact due to the compounding effects of habitat loss and altered predator communities (Reynolds and Tapper, 1996). Both apply to marine turtle nesting in Florida. Thus, predator removal is widely-practiced to protect marine turtle nests (US Fish and Wildlife Service and National Marine Fisheries Service, 1991; Stancyk, 1982).

Hobe Sound National Wildlife Refuge (HSNWR) on the east coast of Florida offers undeveloped and protected beach habitat for nesting by loggerhead Caretta caretta, leatherback Dermochelys coriacea, and green Chelonia mydas turtles (US Fish and Wildlife Service, 1996), each of which is threatened or endangered (US Fish and Wildlife Service, 1994). Predator removal has been carried out since 1972 and has been identified as the most important management program at the refuge (Bain et al., 1997). Prior to implementing predator removal, as many as $95 \%$ of the turtle nests on the refuge were destroyed in a year (Bain et al., 1997). Since 1999, HSNWR has contracted with the United States Department of Agriculture, Wildlife Services as the primary means to remove nest predators. Budgets have allowed for annual contracts of approximately one person-month of control. An important issue is how to apply fixed predator removal resources to maximize protection of turtle nests through the 8-month nesting season.

Direct control can locally reduce predator populations, but the removal of animals does not always correlate well to the magnitude of damage reduction (e,g. Conner et al., 1998). Understanding of the dynamics of the damaging species with the affected resource can lead to more efficient and effective strategies for protecting the resource (e.g. Knowlton et al., 1999; Ramsey and Wilson, 2000). For example, a preventative strategy can be used in some situations to efficiently reduce damage by reducing the depredating species before damage begins (Ramsey and Wilson, 2000). This approach was considered for HSNWR, whereby potential nest predators would be removed prior to turtle nesting. A preventative approach requires the predators to be at the beach prior to turtle nesting. However, if predators invade the beach in response to turtle nesting, then understanding spatial patterns and timing of their movement onto the beach facilitates development and implementation of corrective removal strategies.

Whether deciding on preventative or corrective predator removal, a practical and valid method for monitoring the spatial and temporal dynamics of the nest predators would promote informed and efficient predator removal strategies. Unfortunately, an uncomplicated and sensitive technique for monitoring change in raccoon and armadillo activity on the beach has not been available. Predators in general are difficult to observe because of nocturnal or secretive behaviors (Pelton and Marcum, 1977), but an index that tracks changes in the target population within appropriate time and geographic constraints can provide the information necessary to make management decisions (e.g. Caughley and Sinclair, 1994). An important characteristic for a monitoring method is that it should be simple and quickly applied in the field, while providing sufficient sensitivity to reflect changes in predator activity over time or space (Engeman and Witmer, 2000). We present here a passive tracking methodology that we developed to optimize the removal of turtle nest predators at HSNWR.

\section{Methods}

\subsection{HSNWR turtle nesting beach}

The beach at HSNWR is located on the northern portion of Jupiter Island, a narrow, $27-\mathrm{km}$ long barrier island separated from the mainland by the Indian River Lagoon. Another protected area, St. Lucie Inlet State Park, extends north from HSNWR to the St. Lucie Inlet between Jupiter and Hutchinson Islands. HSNWR protects approximately $5.3 \mathrm{~km}$ of beach, which varies in slope and width, but has a well-defined dune line. HSNWR beach is open to the public during daylight hours, but it is accessible only by boat, or by foot from the southern boundary.

\subsection{Predator monitoring}

We developed a passive tracking methodology for monitoring turtle nest predators similar to methods described by Allen et al. (1996) for dingoes Canis lupus dingo, Engeman et al. (2000) for coyotes Canis latrans and coexisting animals, and Engeman et al. (2001a) for feral swine Sus scrofa. However, in each of those applications tracking plots were placed on dirt roads because they were used as travel pathways by the target animals. Although raccoons had been successfully monitored in Texas using this methodology (Engeman et al. 2001b). no roads existed along the beach at HSNWR, and offroad plots were unsuccessful for monitoring raccoons in Texas (Engeman et al., 2001b). We knew of no prior methodology applicable to the HSNWR beach situation that had been tested on armadillos. Thus, we had to identify an alternative criteria for placing plots in the animals' travel ways.

We observed from tracks that most mammals on the beach appeared to follow the dune line. We placed the plots along the base of the dune vegetation, but above 
the high tide line. Plots were approximately $2 \times 3 \mathrm{~m}$. discrectly marked by wooden stakes in two comers to avoid detection by animals or interlerence by humans. and smoothed to produce a good tracking base. The 21 plots were placed approximately $200 \mathrm{~m}$ apart. avoiding a short $(<150 \mathrm{~m})$ beach segment frequented by people (plots would have been trampled by human prints). Plot locations were recorded using GPS. The same 1racking plots were observed at each assessment period.

The number of track sets number of intrusions into the plot) by raccoons. armadillos. or any other potential nest predator was recorded. The number of plot intrusions has been well-documented to provide superior sensitivity over binary measures (Allen et al., 1996: Engeman et al., 2000). The beach substrate made an excellent tracking surface for identifying species and distinguishing the number of intrusions. After $24 \mathrm{~h}$. the plots were examined for spoor and resurfaced (tracks erased and surface smoothed) for the second of two consecutive days of observations. Fair weather conditions prevailed during each of the assessments.

\subsection{Index calculations}

The numbers of sets of tracks found on the ith plot on the $j$ th day. $x_{i j}$, are represented as a linear model:

$x_{i j}=\mu+P_{i}+D_{i}+e_{i j}$.

where the term $\mu$ is the overall mean number of sets of tracks per plot per day for the area being assessed. $D_{j}$ is a random effect due to the day on which an observation was made, with $j=1$ or 2 in our case. $P_{i}$ is a random effect due to the $i$ th plot with $i-1.2,3 \ldots p_{j} \leqslant 21$ representing the number of plots contributing data on the $j$ th day. The $e_{i j}$ represent random crror associated with each plot each day. Neither the plots nor the days were assumed to be independent for calculation of estimates. Thus, variance calculations are based on a nonzero covariance structure among plots and among days. Also, it would be unreasonable to presume that no plots would be rendered unobservable by the elements or other factors on either day at each assessment. Thus. the number of plots contributing data for the calculations is allowed to differ between days. This data structure permits calculation of a passive tracking index (PTI). components of variance, and variance estimates using the methods in Engeman et al. (1998). The PTI was defined mathematically as:

$\mathrm{PTI}=\frac{1}{2} \sum_{j=1}^{2} \frac{1}{p_{j}} \sum_{i=1}^{p} x_{i j}$.

and the PTI variance estimate was calculated according to the following formula:

$$
\operatorname{var}(\mathrm{PTI})=\frac{\sigma_{i}^{2}}{2} \sum_{j=1}^{2} \frac{1}{p_{i}}+\frac{\sigma_{i}^{2}}{2}+\frac{\sigma_{i}^{2}}{2 \geq} \sum_{i=1}^{2} \frac{1}{p_{j}}
$$

where the $\sigma_{i}^{2}$. $\sigma_{i t}^{2}$ and $\sigma_{i}^{2}$ are. respectively, the variance components (Searle el al. 1992) for plot-to-plot variability. daily variability. and random observational variability associated with each plot each day. SAS PROC VARCOMP. with a restricted maximum likelihood estimation procedure (REML) (SAS Institute. 1996) was used to calculate these variance components.

Observations from all tracking plots were used to calculate overall index values for the entire HSNWR beach. Although plot numbers were necessarily small. we also examined invasion of the beach by calculating indices using subsets comprised of just the four southcrn-most and the four northern-most plots.

\subsection{Assessment timing}

Tracking plot observations were made in January. May, and June to correspond to correspond to pre. early, and mid nesting season. Population reduction was evaluated in early August, and repopulation patterns were monitored in mid-August. Post-nesting incubation predator populations were examined in November.

\subsection{Monitoring twrle nesting activity}

All marine turtle nests were counted at deposition. In comparison to loggerhead turtles, relatively few green and leatherback turtles nest at HSNWR. Therefore, all green and leatherback turtle nests. and every fifth loggerhead turtle nest were marked for monitoring reproductive success. A $120-\mathrm{cm}$ long stake was placed on the north-south axis $60 \mathrm{~cm}$ from the clutch. Two $60-\mathrm{cm}$ long stakes were placed $60 \mathrm{~cm}$ east and west of the clutch. All three stakes were labeled according to observation date, location and turtle species, and joined by surveyor's tape. Marked nests were monitored daily for nest depredation, hatchling emergence, tidal overwash. erosion, or other disturbance. Three full days after the first observed hatchling emergence, marked nesis were excavated to determine reproductive success. Nests that exhibited no signs of hatchling emergence were excavated after 70 days for loggerhead and green turtles, and 80 days for leatherback turtles. The numbers of hatched eggs, unhatched eggs, live and dead hatchlings, and live and dead cmbryos in pipped eggs were recorded. All live hatchlings were handled and released in accordance with Florida's Marine Turtle Conservation Guidelines (Florida Department of Environmental Protection, 1996). Mean clutch size, hatching success (percent of eggs that hatched), and emerging success (percent of eggs producing hatchlings that emerged from the nest) were calculated for the 
marked nests that were not depredated or otherwise destroyed.

\subsection{Predator remoral methods}

A comprehensive Environmental $\Lambda$ ssessment identified lethal predator removal as the only practical and legal approach for reducing predation on marine turtle nests at HSNWR (LS Fish and Wildlife Service, 2000). Because raccoons and armadillos are largely nocturnal, removal efforts were carried out at night. This also minimized the potential for human interference, as the refuge is closed to the public at night. Raccoons were captured in live traps and subsequently euthanized. Capture strategies used successfully for armadillos elsewhere required dogs (e.g. Bergman et al., 1995). but were not applied at HSNWR to avoid interference with turtle nesting. Approximately half of the raccoons and all of the armadillos were removed from the beach using a 22 cal rifle equipped with a noise suppressor and night vision equipment. thus maximizing hunting success while minimizing disturbance. The timing of the removal efforts was determined by the results of predator monitoring and observed predation levels.

\subsection{Metrics of efficacy}

The reduction in the PTI values provided one measure of efficacy for the removal efforts. However. the magnitude of damage reduction is the ultimate measure of efficacy (c.g. Fall. 1980). Thus, we contrasted the predation rate we observed in 2000 to predation rates observed in preceding years under different predator removal regimens. These yearly programs represented a hierarchy of increasing sophistication towards predator removal:

2000: Some refuge predator removal, contrace with control specialists ( 1 person-month), spatial and temporal predator monitoring.

1999: Some refuge predator removal. contract with control specialists (1 person-month), no predator monitoring.

1998: Refuge predator removal. no contract with control specialists and no predator monitoring.

Pre-1972: no predator removal.

We also estimated the number of hatchlings that would have been lost to predation under each of the earlier circumstances if they had been applied in 2000 . We used the 2000 data on the number of nests for each turtle species, the average clutch size for each species, the emergence rate for each species from nests that were not destroyed by predators or other means. and the predation rates on nests of each species under each of the predator removal regimens (present data: Ecological Associates. 1999, 2000). and historical high damage levels (Bain et al. 1997) to predict the number of hatchlings that would have been lost had each predator removal circumstance been applied in 2000 . These calculations relied on the assumption that had each control scenario been applied in 2000. the same predation rates for each species would have resulted as the year in which they were applied and can be summarized in the following equation:

$L_{i j}=N_{i} \times C_{i} \times E_{l} \times P_{i j}$.

where $L_{i j}=$ the number of hatchlings of the $i t h$ species predicted lost in 2000 assuming the predation rate on the $i$ th species nests under the $j$ th predator removal condition, $N_{j}=$ number of nests for the $i$ th species in 2000. $C_{i}-$ the average clutch size for the ith species in 2000. $E_{i}=$ emergence rate for $i$ th species in 2000. $P_{i i}$ - the predation rate on the ith species nests under the $j$ th predator removal condition. $i=$ loggerhead. grecn. or leatherback turtle. $j$ - refuge control *- control contract - monitoring (2000), refuge control - control contract (1999). refuge control without contracting with specialists (1998). no predator removal (historical high predation).

\section{Results}

Raccoons were readily detected by the passive tracking plot method, but it appeared that armadillos were less likely to use a predictable route of travel. reducing the probability of intrusion into at tracking plot. Nonetheless, information generated from both species became an integral component of the predator removal program. We often found fox tracks in our plots. but we found no evidence of foxes as a primary predator on turtle nests. Fortunatcly, our tracking plots showed no evidence that coyotes had expanded their range from nearby on the mainland to Jupiter lsland. We found no track evidence that raccoons or armadillos either avoided or were attracted to the tracking plots. No trail of tracks deviated from its route loward or away from the plots. Tracks on the plots appeared strictly as intersections with the natural travel patterns of the animals.

The initial indexing session in January demonstrated low numbers of predators along the beach (Table 1). thereby eliminating preventative control as a management strategy. Turtles began nesting heavily in midMay and the nesting rate accelerated through June into July (Table 2). Recognizing the difficulty in describing a dynamic system that simultaneously involves nest deposition. hatching. predation and other forms of nest 
Table 1

Passive tracking index fand St) values from Hobe Sound רational Wildife Refuge beach for 2000 using: the 21 plots spanning the length of the beach. the four plots nearest the southern boundary. and the four plots narest the northern boundary

\begin{tabular}{|c|c|c|c|c|c|c|c|c|}
\hline \multirow[t]{2}{*}{$D_{i 1 t}$} & \multirow[t]{2}{*}{ Specis: } & \multicolumn{2}{|c|}{ All Plots } & \multicolumn{2}{|c|}{ South Plots } & \multicolumn{2}{|c|}{ Vorth Plots } & \multirow[t]{2}{*}{ Frent lime frame } \\
\hline & & $P[1$ & $\mathrm{SE}$ & PII & $\mathrm{SE}$ & PTl & $\mathrm{SH}$ & \\
\hline \multirow[t]{2}{*}{ mid-Januaty } & Raccoon & 0.07 & 0.07 & [1. 1.3 & 0.13 & $0 .(\mathrm{H})$ & 0.00 & \multirow[t]{2}{*}{ Pre-lurtle nesting } \\
\hline & Armadillo & $0.0 ?$ & 0.02 & 0.13 & 0.13 & 0.00 & 0.00 & \\
\hline \multirow[t]{2}{*}{ mid-Maly } & Raccoon & 0.31 & 0.22 & 0.00 & 0.00 & 0.25 & 0.25 & \multirow[t]{2}{*}{ Vesting fully under waly } \\
\hline & Armadillo & 0.00 & 0.00 & 0.00 & 0.00 & 0.00 & 0.00 & \\
\hline \multirow[t]{2}{*}{ Early June } & Raccoon & 1.17 & 0.51 & 0.00 & 0.00 & 2.63 & 1.03 & \multirow[t]{2}{*}{ Pre-predator ramoval } \\
\hline & Armadillo & 0.05 & 0.03 & 0.00 & 0.00 & 0.13 & 0.13 & \\
\hline \multirow[t]{2}{*}{ Farly August } & Raccoon & 0.14 & 0.06 & 0.38 & 0.38 & 0.00 & 0.00 & \multirow[t]{2}{*}{ Post-predator removal } \\
\hline & Armadillo & 0.05 & 0.03 & 0.00 & 0.00 & $(1.00$ & 0.00 & \\
\hline \multirow[t]{2}{*}{ mid-August } & Raccoon & 0.20 & 0.16 & 0.38 & 0,38 & 0.00 & 0.00 & \multirow[t]{2}{*}{ Re-invasion } \\
\hline & Armadillo & 0.05 & 0.03 & 0.00 & 0.00 & 0.00 & 0.00 & \\
\hline \multirow[t]{2}{*}{ mid-Norember } & Raccoon & 0.05 & 0.03 & 0.13 & 0.1 .3 & 0.00 & 0.00 & \multirow[t]{2}{*}{ Post-nesting and incubation } \\
\hline & Armadillo & 0.00 & 0.00 & 0.00 & 0.00 & 0.00 & 0.00 & \\
\hline
\end{tabular}

Table 2

Deposition of turtle nests over time during 2000 nesting at Hobe Sound National Wildlife Refuge. FL

\begin{tabular}{lcccr}
\hline Month & Loggerhead & Green & Leatherback & Total \\
\hline March & 0 & 0 & 4 & $\ldots$ \\
April & 6 & 0 & 8 & 4 \\
May & 281 & 0 & 16 & 297 \\
June & 592 & 33 & 8 & 633 \\
July & 452 & 61 & 0 & 513 \\
August & 67 & 38 & 0 & 105 \\
September & 1 & 1 & 0 & 2 \\
Total & 1399 & 133 & 36 & 1568 \\
\hline
\end{tabular}

destruction, the maximum number of nests available for predation during the season occurred in July (Table 3 ). The raccoon index showed a modest increase at the mid-May assessment from the January assessment, followed by a dramatic increase 2 weeks later in the first week of June. The more remote northern plots showed particularly high activity early (May-June) in the nesting season (Table 1). even though the southern third of the beach had over twice the nesting activity. This observed surge in activity and the concomitant predation precipitated the first round of predator removal, which used about three-quarters of the contract funds. The tracking plot data provided strategic information on where to most effectively concentrate predator removal efforts for hunting both species and for locating traps for raccoons. Activity of armadillos at tracking plots aided in identifying saw palmetto Serenoa repens backing up to the dune line as the habitat predictor for identifying where armadillos would most likely be

Table 3

The monthly number of nests marked for inclusion of the sample to be monitored. the number predated by raccoons and or armadillos. and the number removed from monitoring by hatching or another form of nest destruction besides predation (e.g. washout). the number excavated to examine reproductive parameters. and the average number available for predation at Hobe Sound National Wildlife Reluge. FL 2000

\begin{tabular}{|c|c|c|c|c|c|}
\hline \multirow[t]{2}{*}{ Month } & \multicolumn{5}{|c|}{ During each month. the number of nests } \\
\hline & $\begin{array}{l}\text { Included } \\
\text { in sample }\end{array}$ & Depredated & $\begin{array}{l}\text { Otherwise } \\
\text { removed }\end{array}$ & Excavaled & $\begin{array}{l}\text { Avatilable for } \\
\text { predation }\end{array}$ \\
\hline March & 4 & 0 & 0 & 0 & 4 \\
\hline April & 9 & 1 & 0 & 0 & 12 \\
\hline May & 74 & 9 & 1 & 1 & 75 \\
\hline June & 157 & 23 & 6 & 3 & $2(0)$ \\
\hline July & 151 & 43 & 0 & 59 & 249 \\
\hline August & 50 & 30 & 14 & 116 & 139 \\
\hline September & 2 & 17 & 13 & 82 & 29 \\
\hline October & 0 & 1 & 8 & 19 & 1 \\
\hline Vovember & ) & 0 & 1 & 0 & 0 \\
\hline lotal & 447 & 124 & 43 & 280 & $\mathrm{NA}$ \\
\hline
\end{tabular}

found. Predator removal was discontinued by 3 July. after 12 raccoons and 5 armadillos had been removed.

Raccoon activity. which had increased through the June assessment, exhibited an abrupt decline following predator removal to a mid-August index level less than half the mid-May assessment (prior to the rise in raccoon numbers in response to turtle nesting). In contrast to earlier assessments, the southern plots provided an indication of possible raccoon invasive pressure from urban areas south of HSNWR during the two August assessments (Table 1). The index values for those plots increased even though the overall and northern plot 
values decreased. The armadillo index was constant at its high value during the summer assessments. A steady armadillo population and an indication of possible reinvasive pressure by raccoons from the south (Table 1). precipitated another round of predator removal during mid-August. The November assessment demonstrated only minimal beach use by predators after nesting and incubation were finished.

All predator removal approaches appeared beneficial in contrast to historic high predation levels of up to $95 \%$ (Fig. 1). When a contract with control specialists was added in 1999 to the predator removal carried out as part of refuge operations, overall predation dropped from 48.4 to $41.6 \%$. Addition of spatial and temporal predator monitoring to the predator removal contract in 2000 further reduced predation to $27.7 \%$. Similarly. the $29.3 \%$ predation on loggerhead nests in 2000 was a substantial improvement over the $45.3 \%$ rate in 1999 . and the $49.8 \%$ rate in 1998 (tig. 1 ).

The predicted numbers of hatchlings lost under the four predator management scenarios further distinguished the efficacy of the different strategies (Table 4). The nesting results in Table 5 define the parameter framework for estimating the potential impacts of predation on hatchling production in 2000. If no predator removal was applied in 2000 and a historic high predation rate of $95 \%$ occurred. we estimated that 120.597 hatchlings would have been lost. Assuming predator removal was applied without benefit of a contract with control specialists. an estimated 62.481 hatehlings would have been lost in 2000. Addition of the contract with control specialists would have decreased the number to 53.778. Predator monitoring to optimize the application of the predator removal contract resources reduced hatchling loss to 36.637 .

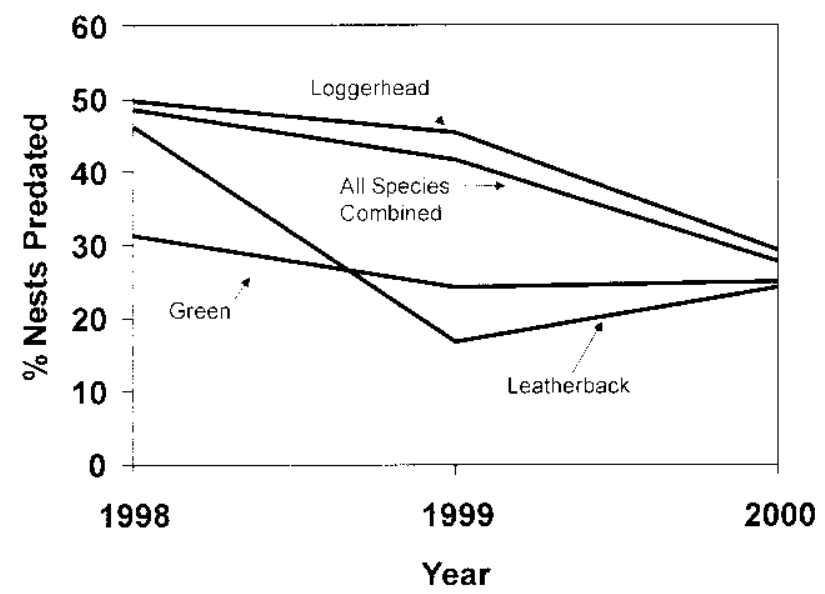

Fig. 1. Percent of marked nests depredated by raccoons and or armadillos during the 2000 nesting season at the Hobe Sound National Wildlife Refuge. Florida. The data from 1999 and 1998 are respectively, from Ecological Associates (2000) and Ecological Associates (1999).
Table 4

The predicted mumber of potential hatchlings fost in $2(40)$ at the Hobe Sound Vational Wildife Refugc. Florida due to nest predation when assuming the predation rates for 2000.1999 .1998 and historital levels of predation (95" a). Predation rates on each species of turta nest are griven in Table 3

\begin{tabular}{|c|c|c|c|c|}
\hline $\begin{array}{l}\text { Sear prosiding predation } \\
\text { rate }\end{array}$ & Loggerhaid & Grwn & $\begin{array}{l}\text { Leither- } \\
\text { bitck }\end{array}$ & Total \\
\hline $\begin{array}{l}\text { 2000. controd contract - } \\
\text { monitoring }\end{array}$ & 33.239 & 2957 & +41 & 36.637 \\
\hline 1999. control contract & 51.391 & 1960 & 427 & 53.778 \\
\hline $\begin{array}{l}\text { J998. control without } \\
\text { contrict }\end{array}$ & 56.490 & 5433 & 552 & $62 .+81$ \\
\hline Hestorical high. no control & 107.773 & 11.148 & 1676 & 120.597 \\
\hline
\end{tabular}

Table 5

Sumnary reproductive information for non-depredated marked sea turtle nests at Hobe Sound National Wildlife Refuge. I:L 2000)

\begin{tabular}{|c|c|c|c|}
\hline Reproductive parameler & $\begin{array}{l}\text { Joggerheild } \\
\text { neits }\end{array}$ & $\begin{array}{l}\text { Grewn lurth } \\
\text { nests }\end{array}$ & $\begin{array}{l}\text { leatherback } \\
\text { nests }\end{array}$ \\
\hline $\begin{array}{l}\text { Number of nests at } \\
\text { HSVWR }\end{array}$ & 1.394 & 133 & 36 \\
\hline Mean Clutch Sire & 108.7 & 126.4 & (6).6 \\
\hline Halching Rate & $75,4^{0} 6$ & $71.6^{60}$ & $73.3^{60 \mathrm{in}}$ \\
\hline Emergence Rate & $74.6 ": 6$ & $69.8^{1+4}$ & $70.4^{\circ} \mathrm{i}$ \\
\hline
\end{tabular}

Thus, about 83.960 more hatchlings were estimated as produced in 2000 than if no predator removal was applied.

\section{Discussion}

HSNWR is located in one ol most important marine turtle nesting areas in Florida (Meylan el al.. 1995), and is in the center of loggerhead nesting activily in the US. The Atlantic green and leatherback turtles comprise only small proportions of the nesting concentrations at HSNWR, but their populations are considered at greater risk (endangered) than the loggerhead's (threatened). and production at even small nesting sites is important. Therefore, minimization of predation. the single greatest annual threat to the turtle nests. is of great importance to the conscrvation of these species.

Predator removal has been determined to be the most practical means to enhance turtle nesting success (Bain et al., 1997). We used our methodology to optimize the impact of restricted resources for predator removal efforts by: (1) optimizing the timing and strategy for application of predator removal. (2) minimizing labor by identifying areas where predator removal would have maximal effect. (3) examining beach invasion patterns of predators. (4) assessing predator removal efficacy, (5) providing anticipatory information for future turtle nesting seasons. and (6) serving as a detection method 
for invasion by additional species known to depredate turtle nests.

Following our detemination that at preventative damage reduction strategy would have been unsuccessful, subsequent predator monitoring allowed precise timing of corrective control when intervention was waranted. In addition. the tracking plots provided a practical view of predator activity along the full length of HSNWR beach. informing control personnel where to focus removal efforts to achiere the greatest impact on both species. Thus, predator removal efforts concentrated on the high activity sections, whereby minimizing time and labor. The PTI indicated a high degree of success at reducing raccoon activity. and provided the basis for discontinuing the first round of predator removal. This reserved sufficient funds to reimplement predator removal in August after armadillos demonstrated a steady presence and raccoons appeared to be re-populating. The best measure of efficacy was the reduction in predation and increase in productivity of the turtle nests in comparison to previous predator removal approaches. Beach invasion patterns and liming for both predators were identified and also provided anticipatory information for future turtle nesting seasons. Continued monitoring would lurther define predator activity patterns, which should lead to greater precision in the timing and spatial focus of future predator removal. Hopefully, a preventative strategy might be integrated with corrective stralegies to further optimize predator removal efforts. For example. we would expect to emphasize predator removal on the north end of the HSNWR beach early in the nesting season, and then expect to encounter more raccoon invasion from the southern portion of the island in mid- to late-summer. Similarly. knowledge of the beach-side habitats most likely to hold armadillos might allow preventative application of armadiflo removal methods prior to nesting that could not be applied during turtle nesting season without interfering with nesting activities. Because the PTI is simultaneously able to detect activity in a suite of wildlife specics. the invasion of coyotes. which are highly destructive predators of turle nosts elsewhere in Florida (Atencio, 1994: Lewis et al.. 1996: Northwest Florida Partnership, 2000), might be delected before a further nest predation problem develops.

Evidence suggests that raccoon migrations to nesting beaches may be cultural (passed on from one gencration to the next). because on some beaches most raccoon predation occurs on the night of egg deposition (Anderson, 1981). while on others, predation rarely occurs then (Fhrhart and Witherington. 1986, our HSNWR observations). A culturally produced migration to a nesting beach could be lost over a few generations through distraction by other easy food resources and predator removal efforts. However. HSNWR presents a more complicated scenario that potentially promotes this behavior. The town of Jupiter Island is on the barrier island adjacent to the southern refuge border. and it supports high raccoon populations (H. Smith. Florida State Parks District Biologist. personal communication. and personal observations). Because a large proportion of the town s residents live elsewhere during turtle nesting (heal and humidity of summer). raccoon food resources may be reduced while turtle egos are readily available nearby in great quantity. Continued monitoring of raccoon invasion from the urban areas south of the refuge may lead to strategies and justification for managing these animals in town for endangered species protection.

Not surprising for observations on predator activity. variance estimates for the index values were often high relative to the index value, especially when calculations were made using subsets of data from only four plots. The variance components calculated for use in the PTI variance formula provided the relative contributions of the sources of variation, useful planning information for optimizing the numbers of days and plots for observations (e.g. Searle et al.. 1992). The plot-to-plot variation $\left(\sigma_{p}^{2}\right)$ usually exceded the day-lo-day variation $\left(\sigma_{d}^{2}\right)$. but random observational noise $\left(\sigma_{c^{2}}^{2}\right)$ most often was the largest contributor to total variability. The low variability among days suggests that observations for more than two consecutive days are not necessary if the outlook is for consistent good weather. Otherwise, the number of observation days should be increased. or the assessment delayed.

The PTI should not be used to directly compare population levels of different species. because index values among species would be confounded with differences in travel behaviors among species. However, index values can be used to identily correlative trends between species (Engeman et al., 2000). We are currently experimenting with tracking methods that might be more sensitive to amadillos without losing cither the quality of raccoon monitoring. or the simplicity of the method in terms of economy and case of application.

\section{Acknowledgements}

S. Breck, K. Fagerstone. M. Fall. T. Mathies. M. Pipas, and M. Stahl provided valuable reviews of earlier versions of this manuscript. J. Bourassat assisted with GPS and GIS applications and N.P. Groninger assisted with computing. C. Crady provided valuable ficld assistance and computing skills.

\section{References}

Allon. L.. Engeman. R.M.. Krupil. H.W. 1996. Fraluation of three relatis abundance indices for assessing dingo populations. Wildlito Research 23. 197206.

Anderson. S.. 1981. The raccoon (Proctom fotor) on St. Catherines 
[sland. Georgia. 7. Nesting seat turtles and foraging raccoons. Americun Muscum Novitates 2713.19.

Alencio. D.E. 1994. Marine turte nesting atelisty on Fglin AFB. Florida. 1987 1992. In: Schroeder. B.A.. Witherington. B.F. \{Eds.\}. Proceedings of the Thirteenth Annual Symposium on Sea Turtle Biology and Conservation. VOAA Technical Memorandum NMIS-SEFSC-341. Springfield. VA. pp. $201 \cdot 204$.

Bain. R.E.. Jewell. S.D. Schwagerl. J.. Veely. B.S. Jr. 1997. Sea Turthe Nesting and Reproductive Success at the Hobe Sound National Wildlife Refuge (Florida). 1972 1995. Report to US Fish and Wildlife Service. ARM Loxahalchee NWR.

Bergman. D.I... Bluett. R.D.. Tipton. A.R.. 1995. An alternative method for capturing armadillos, Southwestern Naturalist 40. +14416.

Caughley. G.. Sinclair. A. 1994. Wildlife Ecology and Management. Blackwell Science. Cambridge. MA.

Conner. M.M.. Jaeger. M.M.. Weller. T.J.. McCullough, D.R.. 1998. Fffect of colote removal on sheep depredation in northern California. Journal of Wibdlife Management 62, 690-699.

Dickman. C.R.. 1987. Habitat fragmentation and vertebrate species richness in an urban environment. Journal of Applied Fcology 24. 337.351 .

Dickman, C.R.. Doncaster. C.P.. 1987. The ecology of small mammals in urban habitats. 1. Populations in a patchy environments. Journal of Animal Fcology 56. 629-640

Drennen. D.. Cooley. D.. Devore, J.E.. 1989. Armadillo predation on loggerhead turle eggrs at two national wildlife refuges in Florida. USA. Marine Turtle Newsletter 1989.7-8.

Ecological Associates. 2000. Hobe Sound National Wildtife Refuge. Jupiter Island Florida Results of 1999 Sca Turtle Monitoring. Report to US Fish and Wildife Service, ARM Loxahatchee NWR.

Ecological Associates. 1999. Hobe Sound National Wildlife Rutuge. Jupiter Island Florida Results of 1998 Sea Turle Monitoring. Report to US rish and Wildife Service. ARM Loxahatchee NWR.

Ehrhart. L.M.. Witherington. B.E. 1986. Human and Natural Causes of Marine Turtle Nest and Hatchling Mortality and their Relationship to Hatchling Production on an Important Florida Nesting Beach. Report to Florida Game and Fresh Water Commission. Tallahassec, $\mathrm{FL}$.

Engeman. R.M.. Allen. L.. Zerbe. G.O.. 1998. Variance estimate for the Allen activity index. Wildife Research 25.643.648.

Engeman, R.M.. Pipas, M.J.. Gruver. K.S., Allen, L.. 2000. Monitoring coyote populations with a passive activity index. Wildlife Research 27. 553557.

Engeman, R.M., Constantin, B.. Nulson. M., Woolard. J.. Bourassia, J.. 200la. Monitoring changes in feral swine population and spatial distribution of activity. Environmental Conservation 28. 235-240.

Fngeman. R.M.. Pipas. M.J.. Gruver. K.S.. Bourassa. J.. Allen. L.. $2001 \mathrm{~b}$. Plot placement when using a passise tracking index to simultancously monitor multiple species of animals. Wildlife Research 28. 17 .

Engeman. R.M., Witmer. G.W.. 2000. 1PM strategies: Indexing dillcult to monitor populations of pest species. Vertebrate Pest Conference 19.183-189.

Fall. M.W. 1980. Management strategies for rodent damage problems in agriculture. [n: Sanchez. F.I. (Ed.). Proc. Symposium on Small Manmals: Problems and Control. Biotrop Special Publication No. 12. Bogor. Indonesia. Pp. $177 \cdot 182$.

Florida Department of Envirommental Protection (currenty Florida Fish and Wildlife Conservation Commission), 1996. Marine Turtle Conservation Guidelines. Florida Deparment of Envirommental Protection. Tallahassee.
Garrott. R.A.. White. P.J. White C.A. 1943, Owerdbundance: an issue for conservation biologists.' Conservation Biology 7.946949. Hecht. A.. Nickerson. P.R.. 1999. The ned for preditor management in conservation of some vulnerable species. Fndingered Species Cpdite 16.114-118.

Knowlton. F.I.. Gese. E.M.. Jaeger, M.M. 1949. Coyote depredation control: an intertace between biology and management. Journal of Range Management 52. $368-412$.

I.ewis. T.F., Atencio. D.. Butgereil. R.. Sheia. S.M. Watson. K. 1996. Sea turtle nesting and namagement in northwest IForida. In Proceedings of the Fifteenth Annual Workshop on Sea Turtle Biology and Conservation. Keinath. J.A.. Bernard. D.F.. Musick. I.A.. Bell. B.A. eds pp162-164. NOAA Fechnical Memorandum NMFS-SEFSC-387. Springfield. VA. ESA.

Meylan. A.. Schroeder. B.. Mosier. A.. 1995. Sea Iurte Vesting Activity in the state of Florida 1979 1992. Florida Marine Research Publication No. 52. Ilorida Marine Research Institute, St. Petersburg.

Northwest Horida Partnership, 2000. Partnership results in protection of sea turtle nests through control of non-native predators on coastal public lands across NW Florida, In: Abstracts LSA. 20th Annual Symposium on Sea Turtle Biology and Conservation. Florida Fish and Wildlife Conservation Commission. Florida Marine Research Institute. St. Petersburg.

Pelton, M.R.. Marcum, L.C.. 1977. The potential use of radioisotopes for determining densities of black bears and other carnivores. In: Phillips, R.L.. Jonkel, C. (Eds.), Proceedings of 1975 Predator Symposium. Montana Forest and Conservation Experimental Station, Missoula, USA. p. 268.

Ramscy. D.S.L.. Wilson. J.W., 2000). Towards ecologically hased bating strategies for rodents in agricultural systems. International Biodeterioration and Biodegradation 45, 18.3-197.

Reynolds. J.C.. Tapper. S.C.. 1996. Control of mammatian predators in game management and conservation. Mammal Review 26. 127 156.

Riley, S.P.D.. Hadidian, J.. Manski, D.A.. 1998. Population density, survival, and rabies in raccoons in an urban nalional park. Canadian Journal of Zoology 76. 11531164.

SAS Institute, 1996. SAS STAT User's Guide. SAS Institute, Carey, NC. USA.

Schmitz. D.C. Brown. T.C., 1994. An Assessment of Invasive NonIndigenous Species in Florida's Public I.ands. Florida Dept. Environmental Protection, Tallahassee. FL.

Scarle, S.R. Casella. G.. McCulloch. C.E.. 1992. Variance Components. Wiley \& Sons. New York.

Smith. H.T. Engeman. R.M. An extratordinary raccoon density at an urban park in Florida. Canadian Ficld Naturalist (in press).

Stancyk. S.E., 1982. Von-human predators of sea lurtes and their control. In: Bjorndal. K.A. (Ed.). Biology and Conservation of Sed Turtles. Smithsonian Institution Press. Washington. DC, pp. 139152.

CS Fish and Wildlife Service. 1994. Fndangered and threatened wildlife and plants. Federal Register. 50,17.11. 17.12.

US Fish and Wildlife Service, 1996. Hobe Sound National Wildlife Refuge. Dept of Interior US Fish and Wildlife Service Publication. RF 41561. Washington, DC.

LS Fish and Wildile Survice. 2000. Fnvironmental Assessment for the Management of Predation Losses to Sea Turtle Nests at the Hobe Sound National Wildlife Refuge. Martin County. FI.

LS Fish and Wildife Service. National Marine Fisheries Service. 1991. Recovery plan for LS Population of Loggerhead Turtle. National Marine Fisheries Service. Washington. DC. 